\title{
JOHN WESLEY AND EPHRAEM SYRUS
}

\section{GORDON WAKEFIELD}

\section{UNITED KINGDOM}

[1] I must begin with an acknowledgement: I am deeply indebted to Sebastian Brock's The Luminous Eye: The Spiritual World Vision of St. Ephraim. ${ }^{1}$ I must note at the outset that this paper brings in John Wesley's brother, Charles, and that it is somewhat speculative.

Like all great men-and in all the Churches there are those who would not dispute his title to that name, though he had plenty of faults-John Wesley had something enigmatic and elusive about him.

It is not easy to describe his spirituality, which was marvellously comprehensive and ecumenical, though highly selective, drawing, as it did, only from the sources that appealed to him. But in trying to do so, we must not forget his origins as the son of Samuel and Susanna, Rector of Epworth and his wife. She bore nineteen children in twenty years, only seven of whom survived, John was the third baby to be so named. We never escape what we have learned at our mother's knee, or through our paternity, which may not be only biological. There was always something of post-restoration high churchmanship about John Wesley with an affinity through his mother with the Non-Jurors, and a preference through the whole family for the Eastern Fathers. Samuel, who expected a curate to read more than the average don

${ }^{1}$ S. Brock, The Luminous Eye: The Spiritual World Vision of Saint Ephrem the Syrian (Cistercian Studies Series 124; Kalamazoo, 1992²). [The author of this article cites the 1st ed., published by the C. I. I. S., 294, Corso Vittorio Emmanuele, IV Piano, 00186 Rome, in 1985.] 
would be capable of, just as John was to make similar demands on his assistants, thought Ignatius of Antioch and his epistles next to the Bible and wished he could have got them by heart. Origen received the highest accolade, though Irenaeus and Basil were lauded and Samuel said "If I were to preach in Greek, St. Chrysostom would be my master."

John Wesley as a theologian came to be in the Augustinian tradition, though he could be scathing about the Latin Fathers. He translated the hymns of German pietists and mystics and succeeeded in empathising with the persecuted Puritans of the previous century, amongst whom had been his grandparents on both sides. But the influence of the Eastern Fathers remained. His interest never flagged and may even have increased as the years wore on, when his evangelicalism, though not his evangelism, was somewhat modified. The "strangely warmed heart" of May $24^{\text {th }}$ 1738 - a phrase with an echo of the Cambridge Platonist, John Smith $(1673)^{2}$-represented a decisive moment at the beginning of his "second journey," to use Fr. O'Collins' terminology. He certainly regarded the period around 1738 as the beginning of his distinctive mission, but the Aldersgate Street experience may have been given undue prominence by Methodists. It was hardly referred to again and as his life went on, Wesley did not repudiate his pre-Aldersgate and Oxford years, emphasising his total dedication to God as a young man of twenty-two in 1725 . He believed (wrongly) that the Church of The New Testament and immediately after, showed a pattern of Christian life near to perfection and that this was unsullied in the pre-Nicene Fathers. His attitude to Constantine was not far removed from the repudiation of Alistair Kee in our own time and he felt that there was a deterioration from the fourth century as what we call Caesaropapism held sway, but there remained pockets of true Christianity, particularly in the East. In 1756, in his "Address to the Clergy," he writes:

Can any who spend several years in those seats of learning (the universities) be excused if they do not add to that of the languages and the sciences, the knowledge of the fathers-the most authentic commentators on Scripture as being both nearest the

${ }_{2}^{2}$ John Smith, Selected Discourses (1673). 
fountain and eminently endued with that Spirit by whom "all Scripture was given" [cf. 2 Timothy 3:16]... I speak chiefly of those who wrote before the Council of Nicea. But who would not likewise desire to have some acquaintance with those that followed thenwith St. Chrysostom, Basil, Jerome, Austin, and, above all the man of a broken heart, Ephraim Syrus? ${ }^{3}$

In another list in one of his sermons, he omitted Jerome and "Austin" (Augustine) and included Macarius, whom we must call "pseudo-Macarius." In his letter of 1749 to the Cambridge deist Conyers Middleton, who asserted that "miraculous powers" ceased with the Apostolic Age, he recognises the Fathers' limitations and mistakes. He does not regard them as powerful intellectuals, but they were Christians and describe "true, genuine Christianity." $\mathrm{He}$ writes "I mean particularly Clemens Romanus, Ignatius, Polycarp, Justin Martyr, Irenaeus, Origen, Clemens Alexandrinus, Cyprian, to whom I would add Macarius and Ephraim Syrus." In that letter, marred by his careless garbling of Middleton's text, he has sixty pages of analysis of patristic authors to refute his antagonist, though Middleton had not written specifically against Wesley. He then turns to his insistence that actual Christian faith and life is as possible now as in apostolic times. The real miracle is not signs and wonders in the natural world so much as Christian life which has "subsisted in the church" in all ages. There is no diminution of the action of the Spirit. The experience of the first Christians, what they knew and felt of Christ may be ours. ${ }^{4} \mathrm{He}$ felt that there were few Christians in his own time, or indeed in any time. But these "burning and shining lights shone in a dark place in a world full of darkness and benighted habitations." 5

John Wesley first read Ephraim in Oxford as a Fellow of Lincoln College in 1732 and continued in Georgia in 1736 and, as we have seen, thereafter. We must never forget that he was a proficient linguist in classical and biblical languages as well as in French and German. It is not easy to deduce which of Ephraim's

${ }^{3}$ Works, ed. Thomas Jackson, X, 484.

4 Works, X, 1-79.

5 Preface to John Wesley, translated and edited, Concise Ecclesiastical History from the Birth of Christ to the Beginning of the Present Century, 4 vols. (London, 1781). 
writings he had studied and read and, as he says read aloud ${ }^{6}$ to his congregations. He read from him to Sophy Hopkey, the eighteenyear-old with whom he fell in love in Georgia-he always longed to share his books with those to whom his susceptible heart drew him. One wonders what the young girl made of Ephraim. Wesley did not publish Ephraim in The Christian Library, his fifty volumes of wide-ranging extracts from the Fathers to the Puritans via some counter-reformation worthies, which was a disastrous publishing venture in his lifetime, but became popular when reduced to thirty volumes in the next century. An extract from Macarius is included. Wesley read Ephraim in sermon preparation. He was too inclined to be influenced by the latest book he had read, but Ephraim was a permanent guide and he included him with authors ancient and modern in his required reading for his assistants. He once said that Ephraim was "the most awakening writer among all the ancients" and translated one of his stories. While there are not as many references to him in his writings as to many other Fathers, and modern interpreters of Wesley do not say much about him, I would single out three particular instances of what is best called by the term sobornost, the fellow-feeling of kindred spirits. As well as these we must note that both Ephraim and Wesley agreed on the freedom of the human will; though Wesley had to assert it in controversy with Calvinists. God's glory is greater if we respond to him of our own free will than if he forces his will upon us and gives us no choice. And both believed that the Eucharist should be celebrated daily. They were both interested in medicine, John Wesley issuing a book of Primitive Physic. But we must turn to the three principal points.

Wesley's devotion to Ephraim was one of his links with the Cappadocian Fathers, which influenced his idea of perfection. Sebastian Brock tells us of the legendary visit of Ephraim to St. Basil. He is repelled by Basil's rich vestments but "recognises him to be the pillar of fire he had seen previously in a vision, for as Basil preached Ephraim beheld the Holy Spirit proceed from his mouth in the form of a dove." Basil is the representative of the Cappadocians of whom Gregory of Nyssa is closest to Ephraim. ${ }^{7}$ And it is Gregory of Nyssa, who, Albert Outler claimed, influenced

${ }^{6}$ Journal, I, 416.

${ }^{7}$ Sebastian Brock, The Luminous Eye (1985) $199 \mathrm{ff}$. 
Wesley through "Macarius" (who was no Egyptian desert Father of the fourth century, as Wesley believed, but a fifth-century Syrian monk, according to the researches of Werner Jaeger). His spirituality was derived from Gregory of Nyssa, as was Ephraim's in part. They saw perfection as a process rather than a state. Says Gregory in his Life of Moses: "This truly is the vision of God, never to be satisfied in the desire to see him." Another metaphor, possibly of relevance to Ephraim, is that one is perfect when after ascending one peak one longs to scale further ranges stretching ahead. Albert Outler believed that this "gave Wesley a spiritual vision quite different from the static perfectionism envisaged in Roman spiritual theology of the period and the equally static quietism of those Protestants and Catholics whom he deplored as 'the mystic writers.".

The Christian "Gnostic" of Clement of Alexandria became Wesley's model of the ideal Christian. Thus it was that the ancient and Eastern tradition of holiness as disciplined love became fused in Wesley's mind with his own Anglican tradition of holiness as aspiring love and thereafter was developed in what he regarded to the end as his own most distinctive doctrinal contribution. ${ }^{8}$

Outler has not wholly convinced other scholars. In a recent paper Frances Young has emphasised parallels between Wesley and the Eastern doctrine of God. They share the distinction, for instance, between the essence and the energies of the Divinity, which is certainly adumbrated in Ephraim's emphasis on the intellect's inability to cross the ontological "chasm." Ephraim and Wesley share an implacable Trinitarianism. Wesley does in his teaching on perfection have too narrow a view of sin, as "the voluntary transgression of a known law," which discounts our unconscious sins which may be worst of all and our involvement in all humankind, so that perfection would seem to be impossible as an individual state or disposition apart from a perfect society. But his definition of Christian perfection as perfect love is a dynamic concept, and he does lay great emphasis on the apostolic "I press on" and says of the soul that dies to sin that the change, like that of our mortal passage, "is of a different kind and far greater than any before and than anyone can conceive till he experiences it." Yet he

8 Albert C. Outler (ed.), John Wesley (Oxford, 1964) 9.10.

${ }^{9}$ Brock 1985, 13. 
still "grows in grace and in the knowledge of Christ" [cf. 2 Peter 3: 18] in the love and image of God and will do so not only till death but to all eternity." 10 This supports Outler's thesis, but Wesley may be thought too eclectic to be bound by any one school or period. ${ }^{11}$

[10] His main preoccupation was not so much with any of his authors as with the Christianity of the eighteenth century. He was not seeking to undertake scholarly research into the spirituality of those to whom he was drawn, but to discover within it what was going to be practical in his own day and what conformed to his own convictions and experience. He was a logician but not a philosopher and his preoccupation was with saving souls, with making it possible for "the vilest offender to turn and find grace," rather than with the study of images and symbolism and poetic philosophy. This I would concede. But Ted A. Campbell writing of the Macarian literature says that Wesley "omitted references to ascetic life and to the notion of theosis 'divinisation' or 'deification'-perhaps the most distinctively Eastern note in the Macarian literature." 12 Ephraim strikes these notes. Is a kindred asceticism and doctrine of theosis in fact absent from Wesley?

This brings me to my second point. Sebastian Brock takes Ephraim as an example "of a native Syrian tradition of the consecrated life which may be termed 'proto-monasticism'." $\mathrm{He}$ was not a monk but lived an intensely devout life in the world. The key term is ibidaya which means single in the sense of unique, as was Christ (though none-the-less he is to be imitated), singleminded, concentrated upon Christ; with an undivided heart; like Adam when first created; and celibate.

[12] Some of this we find in Wesley. Singleness of heart and eye in total devotion to God-in-Christ above all else. And Wesley was much influenced in his first conversion and quest for holiness by Thomas à Kempis's The Imitation of Christ, which he edited and issued for his people, though he thought à Kempis too severe and lacking in his own belief that holiness is happiness. Wesley believed that Christianity was essentially a social religion and to turn it into a solitary one was to destroy it. ${ }^{13}$ "The bible knows nothing of

10 Thoughts on Christian Perfection (1759); quoted Outler 1964, 294.

${ }^{11}$ Henry D. Rack, Reasonable Enthusiast (1989) $101 \mathrm{f}$.

${ }^{12}$ John Wesley and Christian Antiquity (Kingswood Books, 1991) x.

13 Works, V, 296. 
solitary religion. There is no holiness but social holiness." 14 Yet there was need for withdrawal, to commune with God in secret. He would have approved of silent retreats. He wrote Thoughts on a Single Life in 1764, which gathered up his previous teaching. He does not think that the single life is essential to ministry or that marriage is not a holy estate instituted by God, but is clear that a celibate can devote his whole time to God without distractions and endorses the beatitude on those who have made themselves eunuchs for the kingdom of heaven's sake.

He oscillated between thinking that the single life was his vocation and then becoming convinced that it was God's will that he should marry, unfortunately as it turned out. His attitude was psychologically affected by his belief that he would never find a woman of his mother's quality, but there is some truth in Ronald Knox's belief that "his bent, if Providence had not seen fit to order his career otherwise, was towards a solitary, contemplative life." 15 There was a streak of asceticism in him. He lived by rule in Oxford and Knox again is right when he says that "his ideal did not fall short of persuading 70,000 people to adopt, for all practical purposes, the rules of the Holy Club." 16 He contemplated a distinctive dress for Methodists and they were to eschew adornments. He believed in fasting on Fridays and on Wednesdays too, a strict moderation of pleasure, and in eating and drinking, though he recognised the need for some relaxation and the healthgiving properties of wine, in spite of those dangers which led some to counsel total abstinence. He said at one stage "I never myself bought a lottery ticket; but I blame not those that do." Later he had a share in one. But in his Oxford days he enjoyed the society of attractive young women in the Cotswolds. They talked much on serious subjects, though this does not preclude amorous affection by any means; and although somewhat distanced from it, he needed the very different society of those whom he made Methodists after 1738. But he became more serious, more concentrated on holiness as he entered the 1730s and I would say that the authentic Ephraim, like the Gnostic of Clement of Alexandria, represented something of his ideal Methodist.

\footnotetext{
${ }^{14}$ Introduction to Osbron (ed.), Poetical Works.

15 Ronald Knox, Enthusiasm (Oxford, 1950) 431.

16 Knox 1950, 430.
} 
The doctrine of theosis or deification is much misunderstood and misrepresented. It depends on that distinction I have mentioned, of which Frances Young is so well aware, between the essence and energies of God. Ephraim maintains that God intended the human person to become the likeness of God but that humanity "grabbed at divinity out of arrogance" and "lost the reward of divinity which God had intended if free will had properly been exercised. So great, however, is God's love for humanity that, not only does he endeavour to bring Adam/humanity back to Paradise," but "sent his Son who put him on in order to grant him his desire." But "humanity's destined potential of divinity belongs to the eschaton." This status of divinised humanity is achieved solely through grace. There is still what Kierkegaard called "the infinite qualitative difference between God and man." The doctrine of theosis or divinisation, as Ephraim understands it, is just a way of making explicit what it means to become "children of God," seeing that in the Semitic languages, the term bar, "son of," may have the sense of "sharing in the attributes of," or "belonging to the category of." There is an exchange through the Incarnation:

He gave us divinity

We gave him humanity.

That is a quotation from Ephraim. It might just as well have been his contemporary, Athanasius, who wrote: "God became man so that man might become god."17

Now John Wesley opened his Bible at 5 am on May 24th 1738 on 2 Peter 1: 4, that through "the great and precious promises" we may become "partakers of the divine nature," a passage which though some dismiss as late and hellenised is identical with the future imperative of Matthew 5: 48, "Be ye perfect as your father in heaven is perfect," which Luke replaces by "merciful." Wesley insists that perfection, perfect love, is all of grace, just as Ephraim does with divinisation. And it is to be made children of God. "Adopt me by thy grace into thy family."

It is above all in the hymns that theosis has its place in Methodism. And is related to the incarnation:

He deigns in flesh to appear

Widest extremes to join;

${ }^{17}$ Brock 1985, 123-8. 
To bring our vileness near,

And make us all divine

And we the life of God shall know.

For God is manifest below.

Benjamin Drewery has argued that in the last two lines, Charles Wesley "hastens to make clear that this is not theosis." 18 Is to know God's life "very different from sharing his being." This is disputable. Is not knowledge, particularly in the Hebrew sense, participation, union? And in other Wesley hymns there is constant prayer for Christ's likeness, "Give me thyself," and that the Christian may attain, "Fullness of love_of heaven—of God."

Be it I no longer now

Living in the flesh but thou.

[18] Wesley prays to be made "all like God." Christians are to be "transcripts of the Trinity," mirrors of the Deity, temples filled with God,

Plunged in the Godhead's deepest sea

And lost in thine immensity.

[19] It must be admitted that as well as Ben Drewery, John Burnaby, dependent at this point on Frank Weston, questioned the literal truth of Irenaeus's version of theosis. "Because of his immeasurable love he became what we are in order that we may become what he is." "Our love of God will never be past measuring and if we can never reach identification with another human being, far less can we enter into the being of God." The incarnation, he says, is God being taken out of himself to share our humanity and that "the union with God which that knowledge (i.e. through incarnation) gives is the closest union possible here and now between Creator and creature." ${ }^{19}$ There is a dispute here between East and West, of which Wesley may have been innocent, though he is pragmatically somewhat athwart the two. His brother, Charles, however, is even more with the East. There has been a change since Burnaby and Drewery wrote, for instance the rediscovery of the importance of the doctrine of deification in

18 Peter Brooks (ed.), Christian Spirituality (London, 1975) 58.

19 John Burnaby, Christian Words and Christian Meanings (London, 1956) $65 f$. 
Martin Luther, which is indebted to Lutheran-Orthodox dialogue. The old controversy may be dead or dying. ${ }^{20}$

Ephraim has a poem on Virginity in which he contrasts outward and inward circumcision:

With a circumcised heart

Uncircumcision becomes holy

in the bridal chamber of such a person's heart the Creator resides. ${ }^{21}$

[21] On January $1^{\text {st }} 1733$, John Wesley preached a university sermon which, though so early and before Aldersgate Street, encapsulates the doctrine of his whole life. It was on "The Circumcision of the Heart" (Romans 2: 29). Outward forms and observances are not the marks of the true followers of Christ, but rather "a right state at soul, a mind and spirit renewed after the image of him that created it." This is attained by humility, by faith in God, by joyful assurance, but also by "a constant and continual course of general self-denial" and above all by love, "cutting off both the lust of the flesh, the lust of the eye, and the pride of life, engaging the whole person in the ardent pursuit of God." "Let your soul be filled with so entire a love of him that you may love nothing but for his sake."

Thirdly, for both the Wesleys as for Ephraim, poetry was the vehicle of their theology. I would want to claim with Donald Davie and against Lord David Cecil, for instance, that hymns are poetry, certainly in the best examples of the Wesleys. As Sebastian Brock points out poetry "serves as a much needed antidote to that tradition of theologising which seeks to provide theological definitions, Greek horoi or boundaries. To Ephraim, theological definitions are not only potentially dangerous, but they can also be actually blasphemous." In Methodism "our hymns" balance John's perpetual prose arguments with their aim to show the essential Christian truth, orthodoxy and reasonableness of Methodism. In poetry the words point beyond themselves:

it is not at the clothing of the words that one should gaze

but at the power hidden in the words.

${ }^{20}$ Cf. A. M. Allchin, N. F. S. Grundtvig (1997) 325, n. 12.

21 Brock 1985, 104. 
Poetry, says Seamus Heaney, brings human existence into fuller life. It seeks to express the inexpressible by use of images and can represent something of the limitless immensity of God, and the wonder of his being, says Brock. Such a sense of wonder is all pervasive in Ephraim's writings. "Blessed is he who has astounded our thought by the simple things of life" he exclaims.22 But it is wonder above all at the supreme manifestation of God's love for humanity when he "put on humanity;" 23 "it is a matter of wonder that God has bent down to dust." 24 There is much of this in the Wesley hymns, for instance in the one entitled "Free Grace:"

Amazing love! How can it be?

That thou my God shouldst die for me!

'Tis mystery all! The Immortal dies:

Who can explore his strange design?

In vain the first born seraph tries

To sound the depths of love divine.

'Tis mercy all! Let earth adore

Let angel minds enquire no more!

He left his father's throne above,

So free, so infinite his grace,

Emptied himself of all but love

And bled for Adam's helpless race.

[24] The very phrase "The Immortal died" (with the impassable suffered) has been used in the exposition of Ephraim. There is a nativity hymn which, whether consciously or not, echoes Ephraim:

Being's source begins to be

And God himself is born!

Stand amazed ye heavens at this,

See the Lord of earth and skies

Humbled to the dust he is,

And in a manger lies.

It is important that hymns are to be sung, as well as with Methodists, used in private devotion. John Wesley, and in our own century, Dietrich Bonhoeffer, both stressed the spirituality of hymn singing, though the music would be very different from the Syrian,

${ }^{22}$ Hymni de fide (ed. Beck 1955), 43, response.

${ }^{23}$ Hymni de Ieiunio (ed. Beck) 3: 45; Hymni contra Haereses (ed. Beck) 35: 7.

${ }^{24}$ Hymni de fide, 46:11; Brock 1985, 30. 
or any from the East. Ephraim has been called "the real father of Christian hymnography." There seem to be hymns quoted in the New Testament and apart from Psalms and charismatic outpourings ("spiritual songs") they belong to the origins of Christianity, while "Hail gladdening light" was regarded as ancient by St. Basil. Bardesanes of Mesopotamia (154-222) composed 150 psalms and Nepos of Alexandria wrote hymns that were a source of comfort to many in the middle at the third century. There was always a danger that hymns might mean that Christians sang heresy, as with Paul of Samosata whose hymns glorified himself. Ephraim wrote hymns to secure the victory for Nicene orthodoxy, as did Wesley. Ephraim "composed metrical homilies (memre) using the same rhythms as Bardesanes with each verse having the same number of syllables and a set number of accents. They became extremely popular, for when divided into stanzas, they allowed the congregation to participate by singing a refrain (madrosho); sometimes they took the form of acrostic poems (sogbyoto)." 25

John Wesley calls Ephraim, "the man of a broken heart." $\mathrm{He}$ lived at a time of the bitter Arian controversy and when he had to spend the last ten years of his life in Edessa, he found himself surrounded by fierce exponents of conflicting heresies and also gave himself to the victims of famine, rather as the octogenarian Wesley went begging for the poor in the London snow. He was by nature a man at peace whose life was above all, with God and this could not exempt him from some of the sufferings of the incarnate. Eavan Boland has said that "the origins of poetic time must always be in a suffering world rather than in a conscious craft" and maybe there is something of heartbreak in all poetry. But it is Ephraim's Exhortations, which so moved Wesley. He read them, for instance, on Ash Wednesday 1747 and wrote in his Journal, "Surely never did any man since David, give us such a picture of a broken and contrite heart."

There are other images in common-fire for instance. Ephraim frequently describes the divinity as fire. John Wesley wrote of fire as the symbol of love "But truth surpasses figure; and the fire of Divine love has this advantage over material fire that it can re-ascend to its source and raise thither with it all the good

25 A. G. Martimort, The Liturgy and Time (London, 1986) $212 f$. 
works which it produces." 26 One of the greatest and most frequently sung of Charles Wesley's hymns prays that "the flame of sacred love [may burn] on the mean altar of my heart" (Leviticus 6: 113) may "trembling to its source return in humble love and fervent praise." The Lord's words in Luke about him coming to cast fire on earth are interpreted in this and other hymns as referring to Divine love rather than judgement, though the two are not separable.

There are concepts in Ephraim not found in Wesley. Their use and exegesis of scripture would demand another paper, but I do not think Wesley was so much into the spiritual meaning of scripture as into what he thought was its plain, historical sense. He avoids allegory and typology. Nor had he Ephraim's ecological concerns or nature imagery. His movement did result in a certain feminism, the use of women in Methodism, though more in some branches than others. Dinah Morris from George Eliot's Adam Bedehas has only just come into her own.

There has been a legend of Wesley, though not to the extent of Ephraim for obvious reasons. He has been made in the image of those who revered him. Aspects have been exaggerated to conform to the predilections of his interpreters. He has been seen as one who threw off all "rags of popery" after 1738, while others have presented him as essentially the high churchman and in our own time have sought to trace his affinities with Rome, which exist in his love of holiness. There is perhaps more evidence of links with orthodoxy as shown in the little symposium Donald Allchin edited: We Belong to One Another (1965). It would be interesting to compare the legend of Ephraim's dormition with the story of Wesley's deathbed as the evangelicals who crowded it believed they saw the translation of their saint to glory.

I have not gone into the question as to whether Wesley's reading was in Ephraim or Pseudo-Ephraim. That Methodists tended to ignore Ephraim was due to the increasing emphasis on revival rather than nurture, contrary to Wesley, the belief that God would do again what he had done through his Methodist people under Wesley and, spasmodically later on. There was also the fear aroused among evangelicals by the Oxford Movement and its opposition to Methodism as vulgarizing and cheapening the

${ }^{26}$ Works, XI, 441. 
Gospel, which prevented the unity in common understanding of the Fathers which there ought to have been and could be now. But it is moving to imagine that some of the early nineteenth-century preachers, miners, factory workers and fishermen, may have had their sermons shaped by reading on their founder's instructions this Syrian Father of so long before. It is an example of catholicity, or sobornost, which reaches across time, geography and culture and binds all Disciples of Christ in one.

\section{REFERENCES}

Allchin 1997 Allchin, A. (Donald) M. N. F. S. Grundtvig (London, 1997).

Brock 1985 Brock, Sebastian. The Luminous Eye (C. I. I. S., 294, Corso Vittorio Emmanuele, IV Piano, 00186; Rome, 1985).

Brock 1992 Brock, S. The Luminous Eye: The Spiritual World Vision of Saint Ephrem the Syrian (Cistercian Studies Series 124; Kalamazoo, 1992).

Brooks 1975 Brooks, Peter. Christian Spirituality (London, 1975).

Burnaby Burnaby, John. Christian Words and Christian Meanings 1956 (London, 1956) 65f.

Campbell Campbell, E. (Ted) A. John Wesley and Christian Antiquity 1989 (Nashville, Tennessee, 1989).

Curnock Curnock, Nehemiah, ed. Journal of John Wesley, 8 vols. 1909-16 (London, 1909-16).

Jackson 1831 Jackson, Thomas, ed. Works of Jobn Wesley, 14 vols. (London, 1831).

Knox 1950 Knox, Ronald. Enthusiasm (Oxford, 1950).

Martimort Martimort, A. G. The Liturgy and Time (London, 1986).

1986

Osborn Osborn, George. The Poetical Works of John and Charles Wesley, 1868-72 13 vols. (London, 1868-72).

Outler 1964 Outler, Albert C., ed. John Wesley (Oxford, 1964).

Rack 1989 Rack, Henry D. Reasonable Enthusiast (London, 1989).

Smith 1673 Smith, John. Selected Discourses (London, 1673).

Wesley 1759 Wesley, John. Thoughts on Christian Perfection (London, 1759).

Wesley 1781 Wesley, John. Concise Ecclesiastical History from the Birth of Christ to the Beginning of the Present Century, 4 vols. (London, 1781). 